\title{
Prefrontal Dopaminergic and Enkephalinergic Synaptic Accommodation in HIV-associated Neurocognitive Disorders and Encephalitis
}

\author{
Benjamin B. Gelman • Joshua G. Lisinicchia • \\ Tianshen Chen • Kenneth M. Johnson • \\ Kristofer Jennings • Daniel H. Freeman Jr • \\ Vicki M. Soukup
}

Received: 30 August 2011 / Accepted: 6 February 2012 / Published online: 6 March 2012

(C) The Author(s) 2012. This article is published with open access at Springerlink.com

\begin{abstract}
Changes in synapse structure occur in frontal neocortex with HIV encephalitis (HIVE) and may contribute to HIV-associated neurocognitive disorders (HAND). A postmortem survey was conducted to determine if mRNAs involved in synaptic transmission are perturbed in dorsolateral prefrontal cortex (DLPFC) in subjects with HIVE or HAND. Expression of the opioid neurotransmitter preproenkephalin mRNA (PENK) was significantly decreased in a sampling of 446 brain specimens from HIV-1 infected people compared to $67 \mathrm{HIV}$ negative subjects. Decreased
\end{abstract}

B. B. Gelman • J. G. Lisinicchia • T. Chen

Department of Pathology, University of Texas Medical Branch, 301 University Blvd.,

Galveston, TX 77555-0609, USA

K. Jennings $\cdot$ D. H. Freeman Jr

Department of Preventive Medicine \& Community Health,

University of Texas Medical Branch,

301 University Blvd.,

Galveston, TX 77555-0609, USA

K. M. Johnson

Department of Pharmacology, University of Texas Medical

Branch,

301 University Blvd.,

Galveston, TX 77555-0609, USA

\section{M. Soukup}

Department of Neurology, University of Texas Medical Branch, 301 University Blvd.,

Galveston, TX 77555-0609, USA

B. B. Gelman ( $\square)$

University of Texas Medical Branch,

Keiller Building, 3.118, Route 0609,

Galveston, TX 77555-0609, USA

e-mail: bgelman@utmb.edu
DLPFC PENK was most evident in subjects with HIVE and/or increased expression of interferon regulatory factor 1 mRNA (IRF1). Type 2 dopamine receptor mRNA $(D R D 2 L)$ was decreased significantly, but not in the same set of subjects with PENK dysregulation. DRD2L downregulation occurred primarily in the subjects without HIVE or neurocognitive impairment. Subjects with neurocognitive impairment often failed to significantly downregulate $D R D 2 L$ and had abnormally high IRFI expression. Conclusion: Dysregulation of synaptic preproenkephalin and $D R D 2 L$ in frontal neocortex can occur with and without neurocognitive impairment in HIV-infected people. Downregulation of $D R D 2 L$ in the prefrontal cortex was associated with more favorable neuropsychological and neuropathological outcomes; the failure to downregulate $D R D 2 L$ was significantly less favorable. PENK downregulation was related neuropathologically to HIVE, but was not related to neuropsychological outcome independently. Emulating endogenous synaptic plasticity pharmacodynamically could enhance synaptic accommodation and improve neuropsychological and neuropathological outcomes in HIV/AIDS.

Keywords Dopamine receptor - Enkephalin · HAND · HIVE · HIV encephalitis · HIV-associated neurocognitive disorders $\cdot$ Interferon regulatory factor $\cdot$ Opiate $\cdot$ Opioid . Synaptic plasticity

\section{Introduction}

HIV-1-associated neurocognitive disorders (HAND) remain highly prevalent in the era of highly active antiretroviral therapy (HAART) (Heaton et al. 2010; McArthur et al. 
2010). Without HAART the pathophysiology of HAND was significantly linked with high replication rates of HIV-1 in the central nervous system (CNS) and a CNS inflammatory reaction known as HIV encephalitis (HIVE) (Budka et al. 1991). In the era of HAART about $50 \%$ of subjects have neurocognitive impairment to some extent (Heaton et al. 2010 ) but less than $10 \%$ have a neuropathological diagnosis of HIVE (Masliah et al. 2000; Everall et al. 2009). Early in the pandemic it was recognized that HIVE was not present in many subjects with neurocognitive impairment (Glass et al. 1995; Wiley and Achim 1994), and the divergence may have widened in the HAART era (Everall et al. 2009; Gelman 2007). An important role for altered synaptic transmission in HIVE has been widely suggested in the literature. Synaptodendritic simplification is a neurodegenerative type of change that occurs in HAND with HIVE (Masliah et al. 1997), and forms a potential therapeutic concept for translational neuroscience (Gelbard et al. 2010). Transcriptional regulation of genes that code for presynaptic proteins and postsynaptic neurotransmitter receptors and ion channels are perturbed in the dorsolateral prefrontal cortex (DLPFC) of people with HIVE (Masliah et al. 2004; Gelman et al. 2004). Isolated synapses from DLPFC in HIVE contain proteomic changes and altered protein management (Gelman and Nguyen 2010; Nguyen et al. 2010). Many clinical and experimental observations suggest that specific neurotransmitter systems and circuits are disturbed. Examples include striatal dopaminergic circuits (Hriso et al. 1991; Berger and Arendt 2000; Nath et al. 2000; Nath et al. 2002; Wang et al. 2004a, b; Gelman et al. 2006), basal forebrain cholinergic circuits (Sarter and Podell 2000; Koutsilieri et al. 2000, 2001a), peptidergic systems including tachykinins, somatostatin and glutamate (Koutsilieri et al. 2001b; Ho and Douglas 2004; Da Cunha et al. 1995; Ernst et al. 2010; Ferrarese et al. 2001; Meisner et al. 2008; Kovacs and De Wied 1994; Koutsilieri et al. 2001b), and serotonergic systems (Schroecksnadel et al. 2007; Murray 2003). Collectively, anomalies in synaptic transmission imply that neuronal excitability and circuit functions may be abnormal in HAND. In turn, neuroprotective strategies that focus on neuronal excitation and synaptic plasticity could stabilize neural circuitry and prevent HAND (Gelman et al. 2004; Di Filippo et al. 2008; Gelbard et al. 2010). Prefrontal dopaminergic circuits in HIV/AIDS are especially important because they undergo disease-associated changes in synaptic tone that produce abnormal neurocognitive phenotypes (GoldmanRakic 1996; Goldman-Rakic 1998; El-Ghundi et al. 2007; Kroener et al. 2009). Those phenotypes strongly resemble many of the behavioral anomalies that occur in HAND (Chang et al. 2008, Heaton et al. 2010; Woods et al. 2009).

In patients with HAND and HIVE the putative driving force is a combination of brain inflammatory mediators and HIV-1 proteins that participate in multicellular networks that damage "bystander" neuronal elements including synapses (Kaul and Lipton 2006). Many inflammatory mediators expressed in HIVE can produce functional changes in synaptic transmission experimentally. Interferons (IFNs), cytokines including tumor necrosis factor alpha and interleukins influence synaptic long term potentiation (D'Arcangelo et al. 1991; Jankowsky and Patterson 1999; Tancredi et al. 1992; Dafny et al. 1996; Mendoza-Fernandez et al. 2000; Cunningham et al. 1996; Ross et al. 2003; Hadjilambreva et al. 2005; Dafny and Yang 2005; Maher et al. 2006; Khairova et al. 2009), synaptic plasticity (Albensi and Mattson, 2000; Boulanger et al. 2001; Boulanger 2004; Stellwagen and Malenka 2006; Jakubs et al. 2008; Kawasaki et al. 2008; Steinmetz and Turrigian 2010; Yirmiya and Goshen 2011), and synaptogenesis and maintenance (O'Connor and Coogan 1999; Dafny et al. 1996; Vikman et al. 2001; Kim et al. 2002; Brask et al. 2004; Mizuno et al. 2008; Boulanger 2009; Victorio et al. 2010). IFNs are especially important in HIVE because interferon responsive genes (IFRGs) are the most regulated brain gene expression pathway observed on arrays (Masliah et al. 2004). HIVE is likely to be a prototypal clinical example of neuroimmune-associated synaptic dysfunction, but those interrelationships have not been wellcharacterized in HIV-1-infected brain specimens. To address this we performed neurochemical studies in 513 human brain specimens spanning over two decades of the HIV/AIDS pandemic. Dorsolateral prefrontal cortex (DLPFC) was highlighted because the functional output of DLPFC is abnormal in HAND (Heaton et al. 2010; Woods et al. 2009). Two abnormal neurotransmitter systems were identified and characterized. Associations are addressed concerning frontal lobe dysfunction, neuroimmune changes, neurovirological status, neuropathology and key comorbidities.

\section{Methods}

Brain specimens Preproenkephalin mRNA (PENK) and type 2 dopamine receptor long splice isoform (DRD2L) mRNA concentrations were assayed in a total of 513 frozen human brain samples. 446 were HIV infected patients and 67 were age- gender- and ethnicity-comparable HIV seronegative decedents who died during a comparable time span (Table 1) (Nguyen et al. 2010). 312 out of 446 HIV-infected subjects died in the HAART era (1998 to 2011) and were obtained from the National NeuroAIDS Tissue Consortium (NNTC) (Morgello et al. 2001). Written consent was obtained for subjects at four collection sites in the USA. The following offices maintained institutional review boards (IRBs) that provided oversight for the protection of human subjects: 1) The University of Texas Medical Branch Office of Research Subject Protections; 2) Mount Sinai Medical Center Program for the Protection of Human Subjects; 3) 
Table 1 HIV positive decedents with and without HIV encephalitis and seronegative controls

\begin{tabular}{|c|c|c|c|c|c|c|}
\hline \multirow[t]{2}{*}{ Characteristic } & \multicolumn{2}{|c|}{ HIV Infection ${ }^{\mathrm{a}}$} & \multirow{2}{*}{$\begin{array}{l}\mathrm{p} \\
\text { HIV- vs HIV+ }\end{array}$} & \multicolumn{2}{|c|}{ HIV encephalitis ${ }^{\mathrm{b}}$} & \multirow{2}{*}{$\begin{array}{l}\mathrm{p} \\
\text { HIVE- vs HIVE+ }\end{array}$} \\
\hline & HIV- & $\mathrm{HIV}+$ & & HIVE- & HIVE + & \\
\hline Number of subjects & 67 & 446 & $\mathrm{~N} / \mathrm{A}$ & 354 & 92 & N/A \\
\hline $\mathrm{Age}^{\mathrm{c}}$ & $46.9 \pm 13.6$ & $42.6 \pm 9.6$ & 0.001 & $43 \pm 10$ & $41.2 \pm 7.8$ & 0.106 \\
\hline Gender $(\mathrm{M} / \mathrm{F})^{\mathrm{d}, \mathrm{e}}$ & $53 / 14$ & $384 / 62$ & 0.133 & $299 / 55$ & $85 / 7$ & 0.050 \\
\hline $\operatorname{Race}(\mathrm{W} / \mathrm{B} / \mathrm{A} / \mathrm{O})^{\mathrm{e}, \mathrm{f}}$ & $41 / 20 / 0 / 6$ & $271 / 146 / 6 / 23$ & 0.468 & $218 / 113 / 6 / 17$ & $53 / 33 / 0 / 0$ & 0.091 \\
\hline Hispanic or Latino (yes/no) ${ }^{\mathrm{e}}$ & $16 / 51$ & $88 / 358$ & 0.431 & $65 / 289$ & $23 / 69$ & 0.154 \\
\hline Postmortem freezing interval ${ }^{\mathrm{c}}$ & $15 \pm 11.5$ & $14.5 \pm 14.7$ & 0.787 & $14.1 \pm 13.4$ & $16.0 \pm 19$ & 0.268 \\
\hline $\begin{array}{l}\log _{10} \text { Plasma HIV RNA } \\
(\text { copies } / \mathrm{ml})^{\mathrm{c}}(n=263)\end{array}$ & $\mathrm{N} / \mathrm{A}^{\mathrm{g}}$ & $4.2 \pm 1.5$ & N/A & $4.0 \pm 1.6$ & $5.1 \pm 0.9$ & $<0.001$ \\
\hline $\begin{array}{l}\log _{10} \text { Cerebrospinal fluid } \\
\text { HIV RNA (copies/ml) } \\
(n=191)\end{array}$ & N/A & $2.8 \pm 1.5$ & N/A & $2.6 \pm 1.3$ & $4.2 \pm 1.7$ & $<0.001$ \\
\hline $\begin{array}{l}\text { Blood CD4+ lymphocyte } \\
\text { count }\left(\text { cells } / \mathrm{mm}^{3}\right)^{\mathrm{c}}(n=272)\end{array}$ & N/A & $106 \pm 162$ & N/A & $119 \pm 175$ & $52.3 \pm 64.5$ & 0.007 \\
\hline
\end{tabular}

${ }^{a}$ HIV-, Human Immunodeficiency Virus seronegative; HIV+, seropositive

${ }^{\mathrm{b}}$ HIVE, HIV encephalitis

${ }^{\mathrm{c}}$ Mean \pm standard deviation, Student's $t$ test

${ }^{\mathrm{d}} \mathrm{M} / \mathrm{F}$, Male/female

${ }^{\mathrm{e}}$ Chi square

${ }^{\mathrm{f}} \mathrm{B} / \mathrm{W} / \mathrm{A} / \mathrm{O}$, Black/White/Asian/Other or not known

${ }^{\mathrm{g}} \mathrm{N} / \mathrm{A}$, not applicable

University of California, San Diego Human Research Protections Program; 4) University of California, Los Angeles Office of the Human Research Protection Program. These IRBs reviewed the protocol at regular intervals and gave written approvals continuously over 12 consecutive years to the present. Most HAART-era subjects underwent neurocognitive evaluations and substance use surveys using the NNTC protocol, as indicated in tables and figures. 134 of the decedents with HIV/AIDS were archived in the $20^{\text {th }}$ Century and prior to HAART (between 1988 and 1996) in Galveston, Texas, USA. Texan subjects who underwent a complete autopsy before the NNTC did not undergo a structured neurocognitive evaluation; their pathological characteristics have been reported (Gelman et al. 1996).

Neurocognitive testing, substance use survey, neuropathology Two hundred seventy two out of 312 HAART-era subjects were clinically assessed for neurocognitive impairment by a neuropsychologist. 218 out of 272 underwent a structured battery of neurocognitive tests employed by the NNTC at 6 month intervals until autopsy (Morgello et al. 2001). All results were obtained within 6 months prior to death. A composite normalized impairment $\mathrm{T}$ score was obtained, and seven normalized component neurocognitive domain $\mathrm{T}$ scores were evaluated. The consistency of neurocognitive testing across the four NNTC specimen collection sites was maintained with a structured quality assurance program. Evaluations were scored according to age-adjusted norms and clinical diagnoses were assigned according to modified American Academy of Neurology criteria (Woods et al. 2004). One of four neurocognitive diagnoses was considered: a) No syndromic neurocognitive impairment; b) mild cognitive and motor disorder (MCMD); c) HIV-1-associated dementia (HAD); d) impairment possibly caused by medical factors other than HIV/AIDS (NPI-O). A diagnosis of syndromic impairment included the diagnoses of MCMD and HAD, but not NPI-O. The nosological diagnosis of HAND (Antinori et al. 2007) was not used in the present study because: 1) very few subjects in the NNTC autopsy cohort have a diagnosis of "no HAND," and 2) this study and the NNTC began before the establishment of the nosological diagnosis of HAND.

The Psychiatric Research Interview for Substance and Mental Disorders (PRISM) was used to obtain selfreported lifetime histories of substance abuse and dependence. A quality assurance program was followed to maintain consistency across the four NNTC test sites (Morgello et al. 2006). Neuropathological diagnoses were rendered by NNTC site neuropathologists (B. Gelman, Texas; S. Morgello, New York; E. Masliah, San Diego; D. Commons, Los Angeles). Consistency across all four NNTC collection sites was maintained by using a uniform sampling strategy and following a structured program of quality assurance that 
consisted of frequent face-to-face reviews using a multihead microscope. Criteria used for the nosological diagnosis of HIVE were according to Budka et al. (1991).

Brain dissection and RNA isolation DLPFC was emphasized because gene arrays and proteomic studies indicate that synaptic disturbances occur in that sector (Masliah et al. 2004; Gelman and Nguyen 2010). Frozen samples of DLPFC were dissected from Brodmann areas 9 or 10. The Qiagen RNeasy Lipid Tissue Mini Kit (Cat. No. 74804, Valencia, CA, USA) was used to prepare RNA. About $100 \mathrm{mg}$ of brain tissue was dissected on dry ice and placed in $1 \mathrm{ml}$ of QIAzol and $0.5 \mathrm{~g}$ of $0.5 \mathrm{~mm}$ Zirconia/Silica beads (Cat. 11079105z, BioSpec Products, Bartlesville, OK, USA). Samples were homogenized using three $20 \mathrm{~s}$ pulses in a mini-bead beater. At room temperature $200 \mu \mathrm{l}$ chloroform was added with shaking for $15 \mathrm{~s}$, and after standing 3 min was centrifuge at $12,000 \mathrm{x}$ g for $15 \mathrm{~min}$ at $4^{\circ} \mathrm{C}$. One volume of $70 \%$ ethanol was added to the aqueous phase with mixing. Up to $700 \mu \mathrm{l}$ of the extract was added to RNeasy mini spin columns in a volume of $2.0 \mathrm{ml}$. After centrifuging for $15 \mathrm{~s}$ at $8000 \mathrm{x} \mathrm{g}$ at room temperature the spin was repeated with the remainder of the extract. Columns were washed with $350 \mu \mathrm{l}$ Buffer RW1 and treated with RNase-free DNase I (Cat. 79254, Qiagen, Valencia, CA, USA) at room temperature for $15 \mathrm{~min} .350 \mu \mathrm{l}$ Buffer RW1 was added to the columns and centrifuged for $15 \mathrm{~s}$ at 8000 x g. Columns were washed with $500 \mu$ Buffer RPE twice, and re-centrifuged at maximum speed for 2 min to remove salts. RNA was eluted twice with $50 \mu$ l RNase-free water.

Assay of PENK, DRD2L, IRF1, GAPDH and HIV-1 gag/pol, $m R N A$ expression Bio-Rad iScript cDNA Synthesis Kit (Cat. No. 170-8891, Hercules, CA, USA) was used to synthesize cDNA. $1 \mu \mathrm{g}$ of brain RNA, $4 \mu \mathrm{l}$ of $5 \mathrm{x}$ iScript reaction mix, $1 \mu \mathrm{l}$ of iScript reverse transcriptase was adjusted to $20 \mu \mathrm{l}$ with nuclease-free water. The mixture was incubated for $5 \mathrm{~min}$ at $25^{\circ} \mathrm{C}, 30 \mathrm{~min}$ at $42^{\circ} \mathrm{C}, 5 \mathrm{~min}$ at $85^{\circ} \mathrm{C}$, then held at $4^{\circ} \mathrm{C}$. HIV cDNA was prepared using HIV antisense primer $84 \mathrm{R}$ in a final concentration of $1 \mu \mathrm{mol} / \mathrm{L}$ (Palmer et al. 2003). PENK primer sequences used were: AGAAGGCGAAAGTTACTCCAA and CACCATCAA CAGTTTCCCAC; PENK probe sequence: Fam-ACTAG TGGCCCCAGGCCCCA-TAMRA. Glyceraldehyde 3phosphate dehydrogenase (GAPDH) was used as normalizing gene. GAPDH primer sequences: GAAGGTGAAGGT CGGAGTC and GAAGATGGTGATGGGATTTC; GAPDH probe sequence: Fam-CAAGCTTCCCGTTCTCA GCC-TAMRA. All reagents were from Sigma Genosys (The Woodlands, TX, USA). For each reaction, $12.5 \mu \mathrm{l}$ of 2x JumpStart Taq ReadyMix for Quantitative real time PCR (Sigma, St. Louis, MO, USA) (Cat. No. D7440) was combined with $1 \mu \mathrm{l}$ of cDNA, $3.5 \mu \mathrm{l}$ of $25 \mathrm{mmol} / 1 \mathrm{MgCl}_{2}$, $0.8 \mu \mathrm{l}$ of $10 \mu \mathrm{mol} / 1$ primer mix and $0.5 \mu \mathrm{l}$ of $10 \mu \mathrm{mol} /$ 1 probe adjusted to a volume to $25 \mu \mathrm{l}$ with water. PCR conditions were $2 \mathrm{~min}$ at $95^{\circ} \mathrm{C}, 40$ cycles of $15 \mathrm{~s}$ at $95^{\circ} \mathrm{C}$ and $60 \mathrm{~s}$ at $60^{\circ} \mathrm{C}$. For assay of the long splice isoform of the type 2 dopamine receptor, $1 \mu \mathrm{l}$ of $20 \mathrm{x} D R D 2 L$ primers and probe mix (Cat. Hs01024460_m1, Applied Biosystems, Foster City, CA, USA) was combined with $1 \mu$ l of cDNA, $10 \mu \mathrm{l}$ of $2 \mathrm{x}$ JumpStart Taq ReadyMix, $2.5 \mu \mathrm{l}$ of $25 \mathrm{mmol} /$ $1 \mathrm{MgCl}_{2}$ adjusted to $20 \mu \mathrm{l}$ with water. $G A P D H$ mRNA was used as normalizing transcript in reactions analogous to the above using $1 \mu \mathrm{l}$ of $10 \mu \mathrm{mol} / \mathrm{L}$ GAPDH primer mix and $0.5 \mu \mathrm{l}$ of $10 \mu \mathrm{mol} / \mathrm{L}$ GAPDH probe. For assay of interferon regulatory factor 1 (IRF1), IRF1 mix (Hs00971959_m1), GAPDH mix (Hs99999905_m1) and TaqMan Universal PCR Master Mix (Part No. 4304437) were used (Applied Biosystems, Foster City, CA, USA) with PCR conditions as above. Real time PCR was run using an Eppendorf RealPlex (Hamburg, Germany) and gene relative expression was calculated using the $\Delta \Delta \mathrm{C}_{\mathrm{t}}$ method. Each sample was run in duplicate. Two standard calibrator mRNA isolates from brain were run on every plate when calibration between runs was necessary. Brain HIV RNA was quantified using cDNA derived from the brain total RNA isolated as above. The HIV gag/pol primer and probe sequences were from Palmer et al. (2003). The reaction contained $4 \mu \mathrm{l}$ of cDNA, $12.5 \mu \mathrm{l}$ of Sigma JumpStart Taq ReadyMix, $3.5 \mu \mathrm{l}$ of $25 \mathrm{mmol} / \mathrm{L}$ $\mathrm{MgCl}_{2}, 0.8 \mu \mathrm{l}$ of $10 \mu \mathrm{mol} / \mathrm{L}$ HIV primer mix and $0.5 \mu \mathrm{l}$ of $10 \mu \mathrm{mol} / \mathrm{L}$ HIV probe adjusted to $25 \mu \mathrm{l}$. PCR conditions were as above. RNA copy per microgram of total RNA was calculated using a standard curve using a previously quantified HIV-positive RNA sample as the primary standard. HIV RNA copy per gram of brain tissue was calculated using RNA extraction yield $(\mathrm{mg} / \mathrm{g})$ divided by the starting wet weight of the brain tissue sample.

Statistics HIV-infected subjects with and without HIV encephalitis (HIVE) were compared to HIV negatives and to each other using one-way analysis of variance with post hoc comparisons using Tukey's test. The groups of HIV infected subjects with and without syndromic neurocognitive impairment were compared to each other and the HIV negatives as above. For correlation analysis in which there was little deviation from linearity such as for normalized $\mathrm{T}$ scores, Pearson's product moment correlation was used. Spearman's rank test was used when deviation from linearity was prominent, such as for IRF1. The significance of the correlations was corrected for the false discovery rate (Benjamini and Yekutieli, 2001) using alpha $=0.05$. Using the HIV-infected subjects who underwent the substance abuse survey, multiple logistic regression models with stepwise elimination was used to determine whether nine categories of abuse in the PRISM survey were related to the two 
synaptic mRNAs. These models included any kind of substance abuse as one potential independent variable. The pooled students $t$ test was used when two mutually exclusive groups were compared to each other (such as with major depression versus without, or with Hepatitis C infection versus without). When two correlations were compared to each other (such as the correlations between IRF1 and synaptic markers) the bootstrap approach was used (Efron 1979). The general significance level was $p<0.05$ using a two tailed probability.

\section{Results}

PENK and DRD2L expression PENK had significant betweengroup effects comparing controls to HIV positives with and without HIVE $(F=3.45, p<0.0335)$ (Fig. 1a). The subjects with HIVE had an average decrease of $37 \%(p<0.0252$, Tukey's test); the subjects without HIVE did not have a significant decrease in PENK $(p<0.2049)$. The difference was evident both before and during the HAART era (Fig. 1b,c).

Gene array data have suggested that DLPFC DRD2L mRNA was regulated in HAND (Gelman et al. 2004) and this survey confirmed it (Fig. 1d). There was a significant between-group effect using one-way ANOVA DRD2L ( $F=$ $7.78, p<0.0005)$. $D R D 2 L$ was lower by an average of $26 \%$ in the HIV infected subjects without HIVE $(p<0.0021)$ but was not lower in the subjects with HIVE $(p<0.6117)$. The difference was evident both before and during the HAART era (Fig. 1e,f).

Results with or without HIVE suggested that PENK and $D R D 2 L$ mRNA were not downregulated in the same subjects. Indeed, the two synaptic mRNAs appeared to run in opposite directions in HIV-infected subjects (Fig. 2a). The linear correlation coefficient between the two mRNAs after log transformation was negative and highly significant $(r=-3.36$, $p=3.34 \mathrm{E}-13$ ).
Fig. 1 Preproenkephalin (PENK), dopamine receptor $(D R D 2 L)$, and interferon response factor 1 (IRF1) mRNAs in frontal neocortex in 67 seronegative patients and 446 patients with HIV/AIDS (Panels a, d, g). "Rel. expr." on the ordinate denotes mRNA expression relative to $G A P D H$ mRNA. The 446 subjects with HIV/AIDS were subdivided into groups without and with HIV encephalitis (HIVE) $(n=354$ and 92 respectively). Panels b, c, e, f, h, i show the composite data split into subjects who died before ( $n=111$ and 23) and during $(n=243$ and 69) the era of highly active antiretroviral therapy (HAART). The between group analysis using one-way analysis of variance was significant for $P E N K$ $(F=3.45, p<0.0335), D R D 2 L$ $(F=7.78, p<0.0005)$, and IRFI $(F=7.03, p<0.0010)$. PENK was lower in the subjects with HIVE $(p<0.0252)$; DRD2L was lower in the subjects without HIVE ( $p<0.0021)$; IRF1 was higher with and without HIVE $(p<0.0007$ and 0.0060 respectively). The patterns were present prior to and during the era of HAART. Mean \pm standard deviation
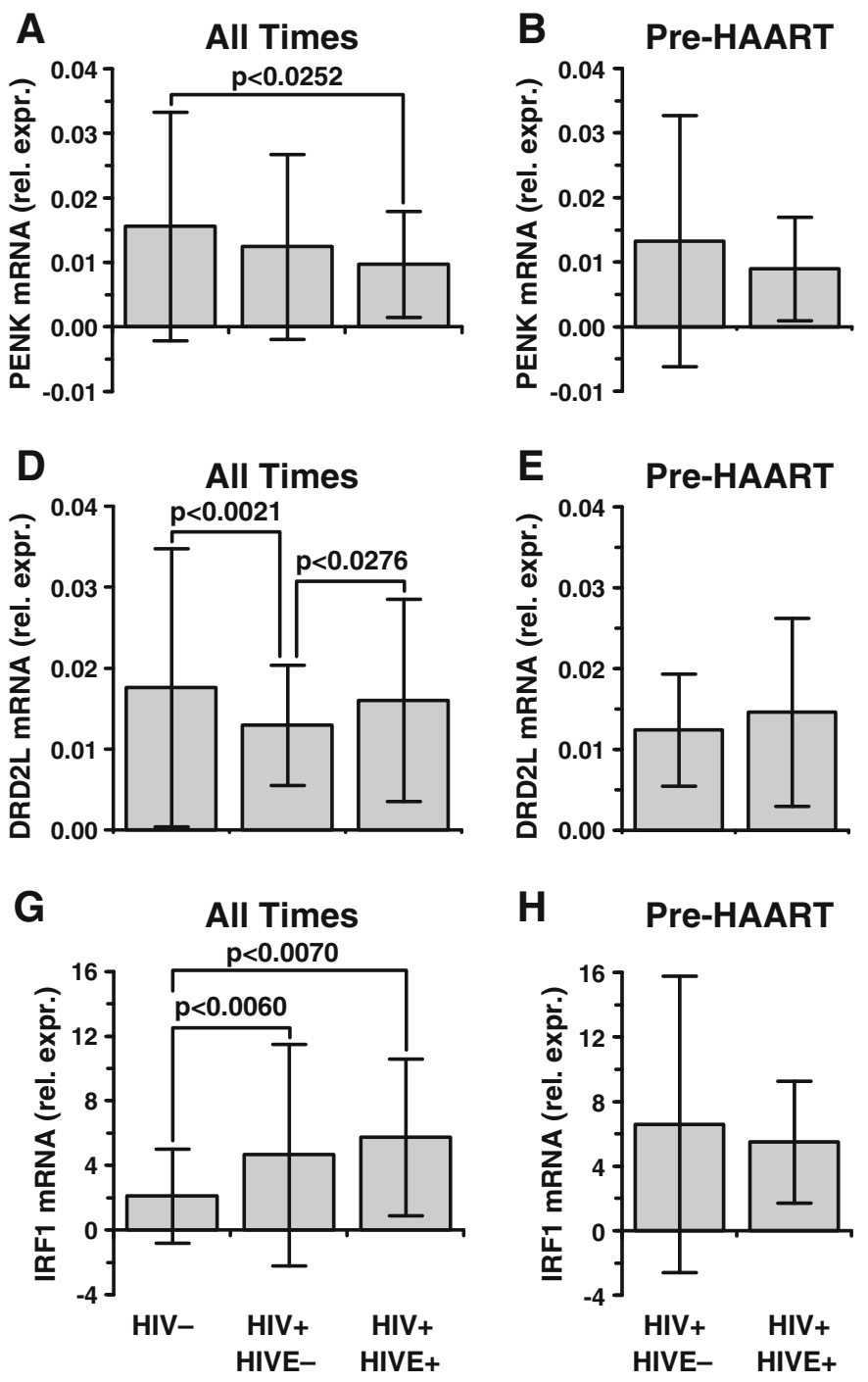

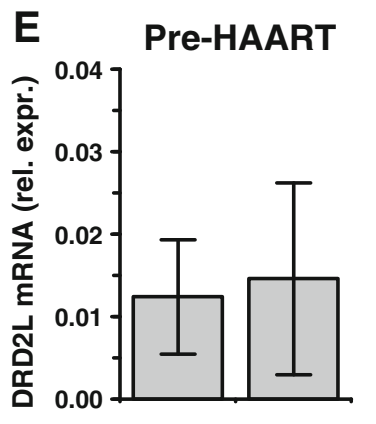

H

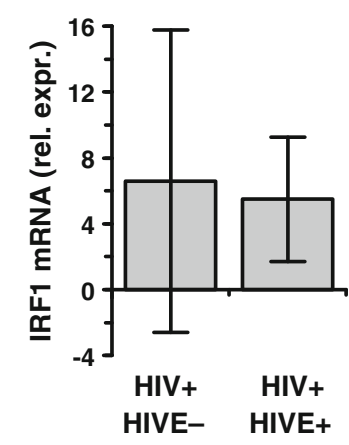

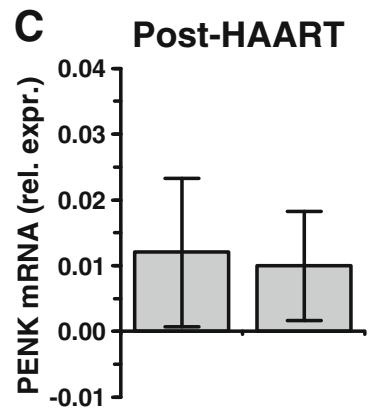

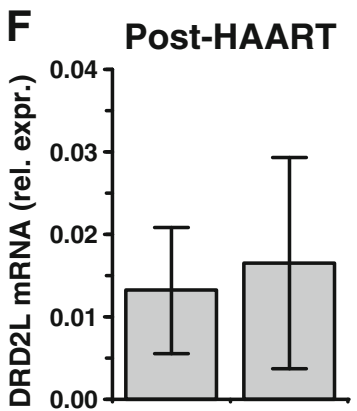

I

Post-HAART

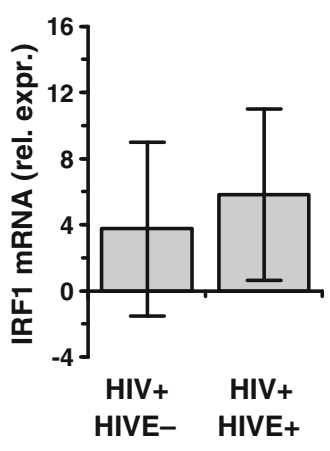



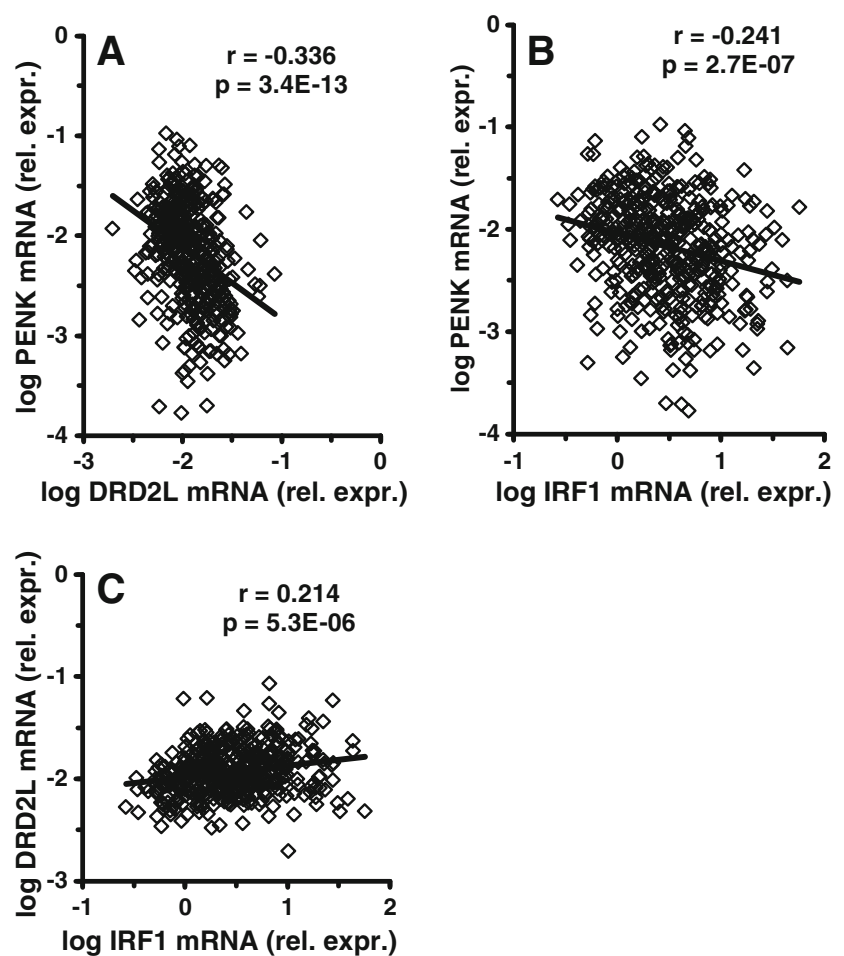

Fig. 2 Changes in preproenkephalin $(P E N K)$ and dopamine receptor $(D R D 2 L)$ mRNA expression in frontal neocortex in 446 HIV-infected subjects. PENK and DRD2L tended to run opposite to each other; the correlation coefficient was significant with a negative slope (a). When compared to the inflammatory marker IRFI mRNA, PENK and $D R D 2 L$ both were significantly correlated. $P E N K$ was correlated with a negative slope (b); DRD2L was correlated with a positive slope (c). Using the bootstrap approach, the correlations in $\mathbf{b}$ and $\mathbf{c}$ are significantly different from each other $(p<0.001)$

Relationship to interferon response The above indicated that HIVE was related to the dysregulation of PENK and $D R D 2 L$. Brain specimens with HIVE usually have higher host neuroimmune responses such as interferon response gene (IFRG) expression (Masliah et al. 2004) and increased brain HIV RNA concentration (Achim et al. 1994). To determine whether IFRG expression was related to the synaptic mRNAs, a prototypal IFRG mRNA was assayed. Interferon regulatory factor mRNA (IRF1) (Gobin et al. 1999) was increased significantly $(F=7.03, p=0.0010)$ by 2.2 fold in subjects without HIVE $(p<0.0060)$, and by 2.7 fold in the subjects with HIVE $(p<0.0007)$ (Fig. 1g). Correlation analysis showed that $\log I R F 1$ was significantly and negatively correlated with PENK ( $r=-0.241, p<2.70 \mathrm{E}-07$, Pearson's test) (Fig. 2b). Log IRF1 was significantly and positively correlated with $\log D R D 2 L(r=+0.214, p<5.30 \mathrm{E}-06)$ (Fig. 2c). Using the bootstrap approach the two correlations were significantly different from each other $(p<10 \mathrm{E}-06)$.

Relationship to brain HIV RNA concentration In contrast to the significant correlations with $I R F 1$, correlation coefficients between the synaptic mRNAs versus log brain HIV
RNA concentration were not significant. A weak threshold concentration of $10 \mathrm{E}+05$ copies of HIV RNA per gram of wet brain tissue was suggested that was significant for increased $D R D 2 L(0.0131 \pm 0.0081$ below versus $0.0154 \pm$ 0.0105 above, $p<0.019$, student's $t$ test), but not for decreased PENK $(p<0.099)$.

Relationship to neurocognitive impairment HIV infected subjects with and without neurocognitive impairment were compared to each other, and to seronegative controls (Fig. 3). One-way ANOVA showed a significant between group effect for DRD2L $(F=5.13, p=0.0065)$ but not PENK $(F=2.36, p=0.0962)$. The post hoc analysis showed that subjects who did not have impairment had a $36 \%$ decrease in DRD2L ( $p<0.0043)$; the subjects who did have impairment had a decrease of $17 \%$ in DRD2L that was not statistically significant $(p<0.1619)$. We performed linear regression analysis using the composite neurocognitive impairment $\mathrm{T}$ score (a normalized measure of composite performance) and found a significant negative correlation with DRD2L (Table 2). The minus sign of the correlation coefficient indicated that lower $D R D 2 L$ expression was linked with stronger performance (a higher T score) and a more favorable neurocognitive outcome overall.

The composite diagnosis of neurocognitive impairment takes into account several component functional "domains" (Woods et al. 2004). To determine whether DLPFC DRD2L expression was correlated selectively with specific types of tasks, multiple correlations using the component domain $\mathrm{T}$ scores were computed (Table 2). Negative correlation coefficients were obtained for performance on tasks that required verbal fluency, working memory formation and rapid information processing. These r-values were significant after correction for the false discovery rate due to multiple comparisons. These tasks are driven characteristically by the frontal lobes, and are modulated by DLPFC dopaminergic tone (Parks et al. 1988; Sawaguchi et al. 1990; Goldman-Rakic 1996; Goldman-Rakic 1998; Gulledge and Jaffe 1998; Schlosser et al. 1998; Baddeley 2003; Tierney et al. 2008; Nagano-Saito et al. 2008; Kroener et al. 2009). For tasks driven primarily by temporal lobe circuits such as learning and memory formation (Squire and Zola-Morgan 1991), the correlation coefficients were not as strong and were not significant after adjustment for the false discovery rate (Table 2).

Relationships to substance abuse history, depression, Hepatitis $C$ virus and age Substance use survey results were available in 194 of the HIV infected subjects. 76 had a least one substance of abuse and 118 had no abuse. The number of subjects in each category of abuse was: alcohol $=50$; cannabinoids $=28$; cocaine $=34$; hallucinogens $=8$; opiates $=11$; sedatives $=17$; stimulants $=28$; other $=7$ (Fig. 4). Multiple 
Fig. 3 Preproenkephalin (PENK), dopamine receptor $(D R D 2 L)$, and interferon response factor 1 (IRF1) mRNAs in frontal neocortex (a, b and c respectively). "Rel. expr." on the ordinate denotes mRNA expression relative to GAPDH mRNA. On the abscissa 67 HIV negative subjects (HIV-) are compared to $146 \mathrm{HIV}$ positive subjects $(\mathrm{HIV}+)$ with neurocognitive impairment (NPI), and 57 HIV+ subjects without NPI.

The between group differences using one-way ANOVA were significant for $D R D 2 L$ $(F=5.13, p<0.0065)$ and IRFI $(F=6.38, p<0.0020)$. DRD $2 L$ was significantly lower in subjects without NPI $(p<0.0043$, Tukey's test). Mean \pm standard deviation
A

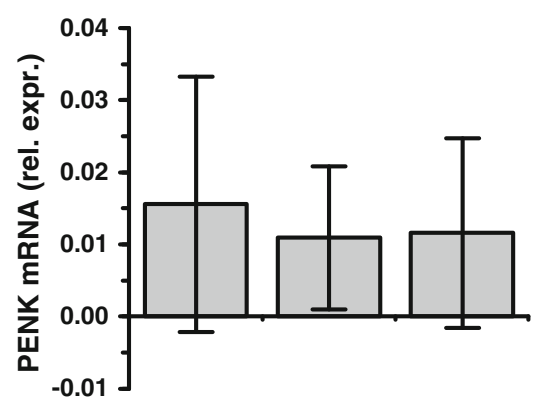

B

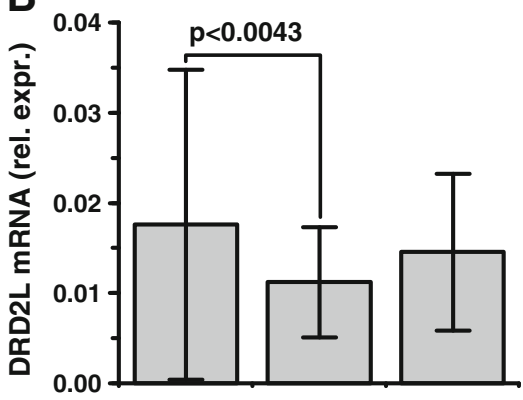

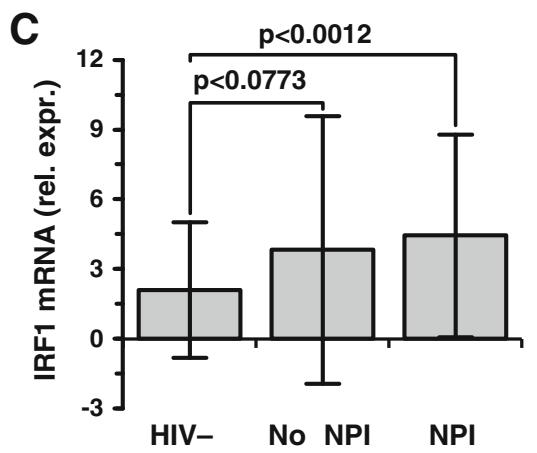

regression models were used to address the fact that multiple substances may be abused. Using DLPFC PENK as the response, the models showed that all p-values were greater than 0.2 , and the overall p-value was not significant $(F=$ 1.293, $p=0.2505$ ) using the Bayesian Information Criterion (BIC). A potentially important $\mathrm{p}$-value for 11 subjects with opiate abuse of 0.0141 was obtained using Akeike's Information Criterion (AIC), implying a possible relationship between opiate abuse and lower PENK expression. Multiple regression models using $D R D 2 L$ as the response showed that all of the $p$-values for the individual categories of abuse were above 0.15 , and the overall $\mathrm{p}$-value was not significant $(F=1.03, p=0.418)$.

The high prevalence of major depressive disorders (MDD) in HIV-infected cohorts (Berger-Greenstein et al. 2007) could influence opioidergic and dopaminergic systems (Peckys and

Table 2 Correlation between normalized neurocognitive T scores and prefrontal synaptic mRNAs

\begin{tabular}{|c|c|c|c|c|c|}
\hline \multirow[t]{2}{*}{ Neurocognitive test domain } & \multirow[t]{2}{*}{$\mathrm{n}^{\mathrm{a}}$} & \multicolumn{2}{|c|}{$D R D 2 L \mathrm{mRNA}^{\mathrm{b}}$} & \multicolumn{2}{|c|}{ PENK mRNA } \\
\hline & & $\mathrm{r}^{\mathrm{c}}$ & $\mathrm{p}^{\mathrm{d}}$ & $\mathrm{r}$ & $\mathrm{p}$ \\
\hline Verbal Fluency & 215 & -0.2450 & $0.0003 *$ & 0.0444 & 0.5168 \\
\hline Attention and working memory & 211 & -0.2180 & $0.0014 *$ & 0.0116 & 0.8661 \\
\hline Speed of Information processing & 216 & -0.1983 & $0.0034 *$ & 0.0232 & 0.7339 \\
\hline Motor & 202 & -0.1675 & 0.0171 & 0.0502 & 0.4778 \\
\hline Learning & 218 & -0.1653 & 0.0145 & -0.0445 & 0.5127 \\
\hline Abstract Executive & 208 & -0.1461 & 0.0352 & 0.0363 & 0.6019 \\
\hline Memory & 217 & -0.1004 & 0.1404 & -0.0916 & 0.1787 \\
\hline Composite $\mathrm{T}$ score, all tests & 196 & -0.2394 & $0.0007 *$ & 0.0051 & 0.9434 \\
\hline
\end{tabular}

${ }^{\mathrm{a}} \mathrm{n}$, number of subjects with available T score

${ }^{\mathrm{b}} D R D 2 L$ mRNA, dopamine receptor type 2 long splice isoform messenger RNA; PENK mRNA, preproenkephalin

${ }^{\mathrm{c}}$ r, Pearson's correlation

${ }^{\mathrm{d}} \mathrm{p}$, Two-tailed probability

*Bold denotes significant statistically after controlling for the false discovery rate. The composite score does not require adjustment; its p-value is significant with or without correction 


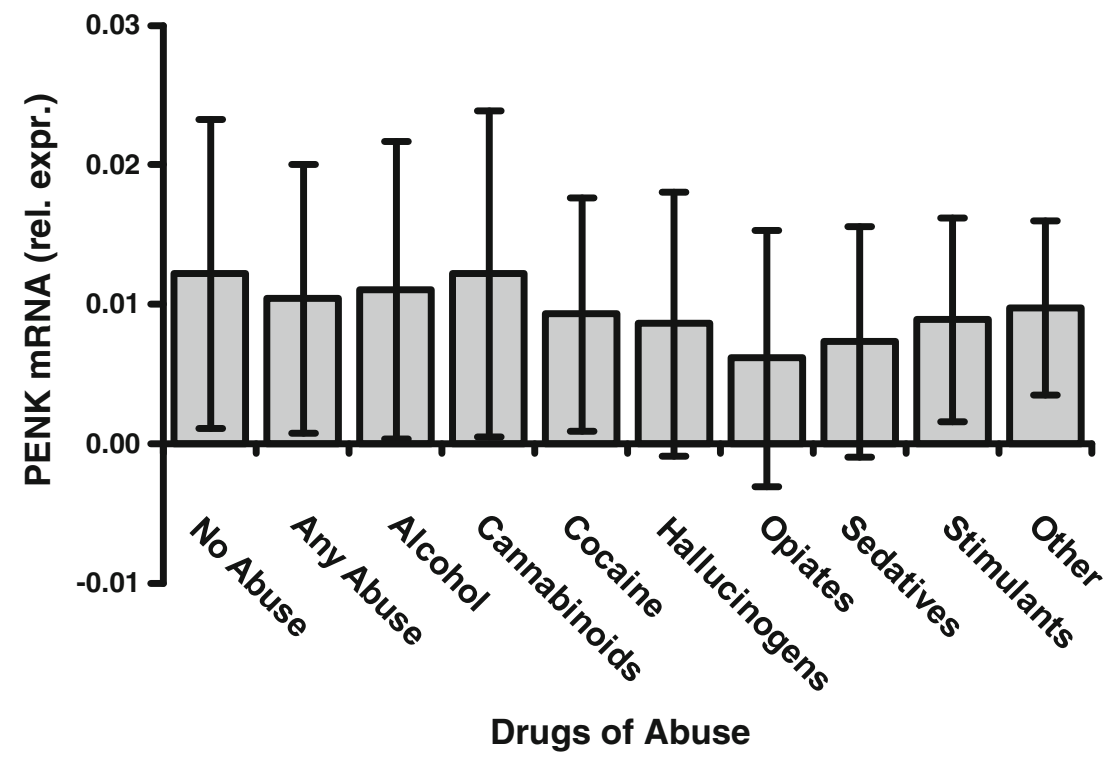

Fig. 4 Preproenkephalin mRNA concentration (PENK) in frontal neocortex of HIV-infected subjects is plotted versus substance abuse categories. "Rel. expr." on the ordinate denotes mRNA expression relative to $G A P D H$ mRNA. Drug abuse was diagnosed using the Psychiatric Research Interview for Substance and Mental Disorders (PRISM). Drug abuse categories are given on the abscissa. "Other" denotes several substances such as inhalants. See "Results" for the

Hurd 2001; Tremblay et al. 2005; Kennedy et al. 2006) and/or the neurocognitive output of the DLPFC (Ottowitz et al. 2002; van der Werf-Eldering et al. 2010). In 91 subjects with MDD versus 100 without it, neither PENK $(0.0105 \pm 0.0087$ vs $0.0123 \pm 0.0120, p<0.264)$ nor $D R D 2 L(0.0130 \pm 0.0095$ vs $0.0132 \pm 0.0079, p<0.892)$ was significantly different.

Hepatitis $\mathrm{C}$ virus (HCV) infection can influence HAND, especially in the presence of MDD (Clifford et al. 2005). The two synaptic mRNAs were not expressed differently comparing subjects with $(\mathrm{n}=79)$ and without $(\mathrm{n}=116)$ documented HCV infection (PENK: $0.0107 \pm 0.0102$ vs $0.0117 \pm$ $0.0104, p<0.504 ; D R D 2 L: 0.0139 \pm 0.0079$ vs $0.0147 \pm$ $0.114, p<0.586$ ).

Advanced age has been reported to be associated with lower DRD2 binding availability to the extent of about $0.6 \%$ per year (Antonini et al. 1993; Volkow et al. 2000), and also with higher brain inflammation (Dickson et al. 1992). The HIV infected subjects in the autopsy cohort were slightly younger than controls (4 years on average, see Table 1), and raised the possibility that a younger average age might have influenced neurochemical outcomes. The $t$-test of the coefficient in a regression model testing the effects of HIV and age together showed that IRF1 was higher $(p<0.001)$, $P E N K$ was lower $(p=0.022)$ and DRD2L was lower $(p=$ 0.0597). Thus, age did not drive the changes observed in HIV infected subjects substantially, although a small influence of age on these outcomes remains difficult to exclude completely. number of subjects in each category. PENK was not significantly different in any substance abuse category using multiple regression models. Compared to subjects without any abuse (left bar), eleven subjects with opiate abuse had a trend towards having significantly less PENK using stepwise regression models that was of marginal significance (see "Results"). DRD2L mRNA also showed no significant group effect (not illustrated). Mean \pm standard deviation

\section{Discussion}

The study confirms that mRNA changes associated with altered synaptic transmission in frontal neocortex are prevalent in people with HIV/AIDS. At least $40 \%$ of the HIV infected population had downregulation of at least one of the two synaptic mRNAs. The abnormal synaptic mRNA pertaining to dopaminergic neural transmission $(D R D 2 L)$ was correlated significantly with neurocognitive impairment, while the abnormal enkephalin-related mRNA $(P E N K)$ was not correlated with impairment independently. The fact that the two synaptic mRNAs were regulated in the opposite direction from each other implies that the changes do not reflect a generalized loss of synapses in the setting of neurodegeneration. Instead, the functional implications of the results pertain to synaptic plasticity and the circuit level output of the frontal lobes. Neurotransmitter "tone" is dynamically regulated in many ways. Modulating the concentration of the neurotransmitter presynaptically (illustrated with $P E N K$ regulation) or changing the number of receptors postsynaptically (illustrated with $D R D 2 L$ regulation) represent established aspects of synaptic plasticity (Malenka and Nicoll 1993; Elgersma and Silva 1999; Citri and Malenka 2008). Changes in synaptic tone at the cellular level produce shifts in neuronal excitation; dopaminergic and opioidergic tone both modify neuronal excitability at the cellular level (Xie and Lewis 1995; Otani et al. 2003). In turn, synaptic plasticity produces coordinated changes in the output of 
neural networks (Citri and Malenka 2008; Boulanger 2004). Clinically, circuit-level changes in DLPFC output modify neurocognitive test performance on tasks pertaining to verbal fluency, working memory formation, and speed of processing (Sawaguchi et al. 1990; Gulledge and Jaffe 1998; Schlosser et al. 1998; Goldman-Rakic 1996; Tierney et al. 2008). All of those kinds of tasks were correlated significantly with DLPFC DRD2L expression in HIV/AIDS (Table 2). Dopamine receptive neurons in the DLPFC that express $D R D 2 L$ play a critical role in controlling the output of frontal lobe circuits (Goldman-Rakic 1998; Wang et al. 2004a, b; Nagano-Saito et al. 2008; Kroener et al. 2009). In primates these neurons are concentrated in the excitatory output neurons in cortical Lamina V. Their excitation state fundamentally controls DLPFC circuit output (Lidow et al. 1998; Wang et al. 2004a, b; Cohen et al. 2002). Enkephalinergic neurons and cognate delta opioid receptors in DLPFC also are localized in Lamina $\mathrm{V}$ and vertically connected neurons in Laminae II and III (McGinty et al. 1984; Mansour et al. 1993). The cortical enkephalinergic system also influences frontal lobe output (Verdejo et al. 2005). Together these abnormal synaptic systems can exert substantial control on the functional output of the frontal lobe circuitry, and thus, might drive frontal lobe dysfunction in HAND and HIVE (Woods et al. 2004).

The type 2 dopamine receptor $(D R D 2 L)$ is a pivotal point of neural circuits that originate in the midbrain, such as the mesofrontal circuit in DLPFC (Goldman-Rakic 1998) and the classical "direct" striatopallidal circuit (Gerfen et al. 1990). DRD2L expression often is a transcriptionally active marker gene in dopamine receptive neurons that responds dynamically to changes in synaptic dopaminergic tone (Gerfen et al. 1990; Angulo et al. 1991; Volkow et al. 1999; Trantham-Davidson et al. 2004; Seamans and Yang 2004; Sesack and Carr 2002), and also can modulate PENK expression (Gerfen et al. 1991; Morris and Hunt 1991; Przewłocka and Lasoń 1995; Steiner and Gerfen 1999). Regulating dopaminergic tone in the mesofrontal circuitry has consequences that are potentially both favorable and unfavorable. DLPFC output responds to dopaminergic tone in an "inverted U" type of dose-response curve, in which excessive deviation in either direction modifies synaptic tone and can produce DLPFC dysfunction (Nagano-Saito et al. 2008; Cools and D'Esposito 2011; Monte-Silva et al. 2009). One stimulus that shifts the inverted $U$ response curve and drives DLPFC DRD2L expression lower is increased presynaptic dopaminergic tone (Ito et al. 2011; Sesack and Carr 2002; Volkow et al. 1999). In HIV/AIDS the functional output of the DLPFC was most favorable when $D R D 2 L$ expression was downregulated, which implies a compensatory shift to a more favorable point on the inverted U response curve. Conversely, DLPFC output was less favorable when $D R D 2 L$ showed no net downregulation
(Fig. 3), which implies a less optimal point on the inverted $U$ response curve. Thus, decreased $D R D 2 L$ expression probably reflects a compensatory lowering of dopaminergic set point to synaptically accommodate, and stabilize DLPFC output (Floresco and Magyar 2006). We suggest that this is the most likely reason why failing to drive dopaminergic tone downward was associated with less beneficial outcomes. The fact that an unfavorable neurocognitive outcome was associated with "normal" $D R D 2 L$ expression is seemingly paradoxical. But those results are in substantial accord with clinical observations, including some work with HIV-infected subjects. Using functional magnetic resonance spectroscopy (MRS) it was shown that many subjects with task-driven functional abnormalities of frontostriatal circuitry, and/or glial activation (Melrose et al. 2008; Ernst et al. 2002; Meyerhoff et al. 1999), do not have HIV-associated neurocognitive impairment. Conversely, many subjects without those synaptic accommodations (i.e. appear "normal" in the brain images) do have impairment. These types of clinical observation in HIV/AIDS, in conjunction with the vast experimental literature on prefrontal dopaminergic systems, suggest the scenarios that are illustrated in Fig. 5: 1) DLPFC dopaminergic circuit accommodation does occur in some subjects with HIV/AIDS. 2) When it occurs it appears to be beneficial to frontal lobe output as depicted in scenario C. 3) When it fails to occur it is potentially unfavorable as depicted in scenario B. 4) Brain inflammation and/or HIVE (represented by the interferon response gene IRF1) seems to drive $D R D 2 L$ expression upward and has an unfavorable influence on DLPFC dopaminergic tone, and possibly, enkephalinergic tone as in Scenario D.

Brain imaging in subjects with HAND has suggested that neostriatal ligand binding availability is low for postsynaptic DRD2 and the presynaptic dopamine reuptake transporter (DAT). Those results are generally taken to suggest that striatal dopaminergic tone is abnormal, although the technical approaches used were not sufficiently sensitive to detect a change in the DLPFC (Chang et al. 2008). Indeed, assay of synaptic mRNAs was the chosen approach at autopsy primarily because detection of neocortical protein elements was out-of-range. Beyond the problem of detection, each dopaminergic circuit has interdependent regulatory properties that often run opposite to each other (Wilkinson 1997; Kellendonk et al. 2006). Despite the technical differences, autopsy results agree that dopaminergic transmission is related to HIV-associated neurocognitive dysfunction. The decreased transcription regulation of $D R D 2 L$ at autopsy is consistent with a loss of raclopride binding availability of DRD2 in the neostriatum (Chang et al. 2008). As well, the suggestion that increased presynaptic tone could drive the changes (as illustrated in Fig. 5) is consistent with having decreased dopamine binding availability of DAT. In the latter scenario, a higher concentration of endogenously 


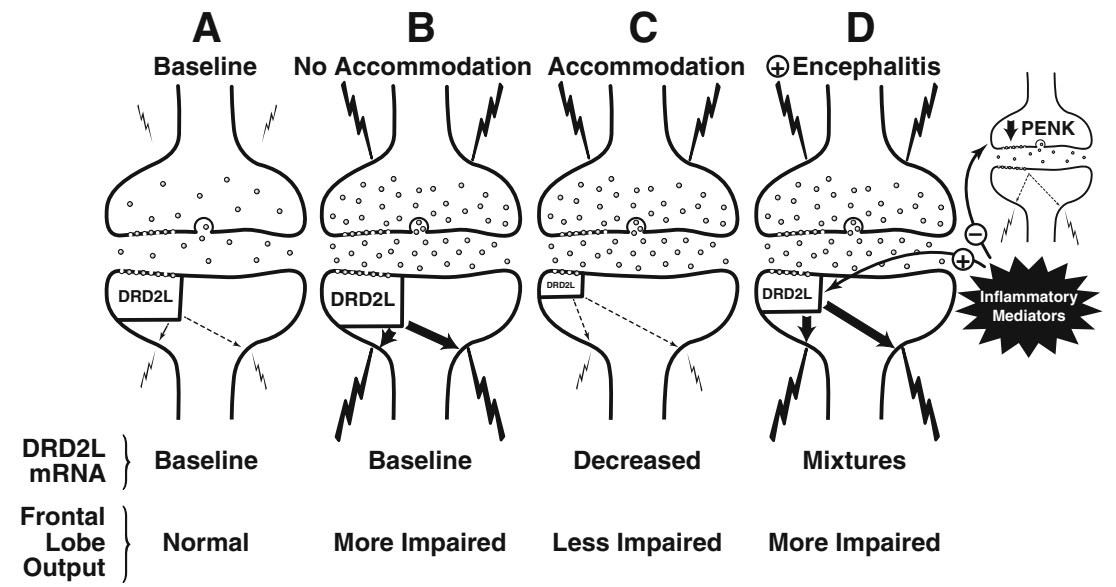

Fig. 5 Prefrontal dopamine receptive neurons in HIV infected subjects often have abnormal mRNA expression of genes that are critical for synaptic transmission. The proposed functional implications for a dopaminergic synapse of a Lamina $\mathrm{V}$ pyramidal neuron are illustrated in four scenarios designated $\mathbf{a}, \mathbf{b}, \mathbf{c}$ and $\mathbf{d}$. Scenario A depicts baseline dopaminergic tone in a normal person. Scenario B depicts no change in postsynaptic $D R D 2 L$; subjects fitting that picture were more likely to have neurocognitive impairment and high excitatory frontal lobe output. Scenario C depicts a decrease in postsynaptic DRD2L due to accommodation; subjects fitting that picture were less likely to have neurocognitive impairment and lower excitatory output. Scenario D depicts HIV encephalitis which produces an increase in inflammatory mediators; subjects fitting that picture probably had bidirectional

synthesized dopamine in the synaptic cleft could compete with exogenous radiotracer dopamine and reduce its binding availability, which is what was observed in neostriatum (Chang et al. 2008).

The mechanism that produces altered dopaminergic transmission in HIV/AIDS is of great interest and needs to be elucidated. Experimental evidence shows that HIV-1 can interact directly with dopaminergic synapses. Specifically, the concentration of HIV-1 transactivator of transcription protein (Tat) which is known to be toxic, influences the physiochemical interplay between dopamine and neostriatal DAT, and could disturb dopamine binding availability to DAT (Zhu et al. 2011). Pertinent to that suggestion, the autopsy survey showed that the concentration of HIV gag/ pol RNA in the brain was not correlated significantly with $D R D 2 L$ expression. A history of taking HAART to suppress HIV replication also showed no apparent relationship at autopsy. Those observations imply that the concentration of HIV-1 proteins such as Tat do not directly drive $D R D 2 L$ regulation. The same could apply to DAT binding availability, although the issue was not addressed specifically at autopsy because presynaptic DAT and its mRNA could not be detected consistently in the DLPFC.

One implication for future work is that inflammatory type mediators such as the IFNs might be directly involved with dopaminergic transmission in HIV/AIDS. Autopsy data implied that inflammation was associated with higher $D R D 2 L$ changes in $D R D 2 L$, including increased expression when inflammation and HIVE were present. Inflammation and HIVE also were associated with decreased $P E N K$ expression, which ran opposite to $D R D 2 L$ regulation. The nature of the suggested connection between dopaminergic and enkephalinergic transmission remains to be elucidated. Key: The presynaptic bouton is on top and postsynaptic bouton is below. For the purpose of illustration, the postulated driver of postsynaptic DRD2L expression is increased presynaptic dopaminergic tone (the cause is not clear). A larger size of the $D R D 2 L$ symbol denotes higher receptor mRNA expression. Bolder arrows denote stronger receptor transduction. Bolder lightning bolts denote stronger depolarization or high firing rates. A high density of presynaptic vesicles symbolizes higher presynaptic tone

and lower PENK (Fig. 2). This was illustrated using a prototypal IFN- $\gamma$-responsive gene (IFRG); other inflammatory mediators produced equivalent results (not illustrated). IFNs and IFRGs are neuroimmune mediators of prime interest because they are strongly expressed in virus infected brain tissue including HIVE (Masliah et al. 2004; Sas et al. 2009). The connection between the IFRG expression and synapse biology in HIV/AIDS agrees fundamentally with a broad base of experimental data (see the extensive list of pertinent citations in the introduction). IFN and other neuroimmune mediators modify synaptic functions directly by driving IFN receptors on neurons (Neumann et al. 1997; Delhaye et al., 2006; Mizuno et al. 2008; Sas et al. 2009; Dafny 1998), and indirectly by increasing the synthesis of IFRGs. IFNs act upon two types of receptors that drive the expression of hundreds of IFRGs (Boehm et al. 1997; Theofilopoulos et al. 2005). Examples of indirect action of IRF-1 include the induction of class I major histocompatibility antigens, and nitric oxide synthesis (Martin et al. 1994; Hobart et al. 1997), which in turn modify synaptic long term potentiation (Garthwaite and Boulton 1995; Goddard et al. 2007). Experimental data show that increased IFN- $\gamma$ also lowers PENK mRNA expression (Low et al. 1992; Negro et al. 1992; Ovadia et al. 1996), as observed in the subjects with HIVE (Fig. 1). Experimentally, the proposed linkage between heightened immune responses and neural transmission can operate in both directions via 
feedback loops. For example, opioid neuropeptides including PENK drive neuroimmune cellular responses forward, including increased macrophage and lymphocyte infectivity with HIV-1 (Nath et al. 2002; Wetzel et al. 2000). A feedback loop is suggested in which heightened neuroimmunity leads to PENK downregulation and weakens HIV-1 replication. Dopamine and serotonin also modify macrophage HIV-1 replication via their cognate receptors, and could engage in similar feedback loops (Maneglier et al. 2008; Gaskill et al. 2009). The suggested scenarios need to be confirmed in model systems focusing on receptor proteins and their endogenous agonists.

Substance abuse is prevalent in HIV-infected populations. It is associated with altered neural transmission (Wolf 2002; De Vries and Shippenberg 2002), including lower striatal $D R D 2$ mRNA expression, and especially with cocaine and methamphetamine use (Volkow et al. 1999; Goldstein and Volkow 2002; Chang et al. 2008). Substance abuse also can change neurocognitive function pertaining to DLPFC output (Nath et al. 2002). The linkage of substance abuse with lower DRD2 expression implies that it also could be associated with synaptic "accommodation" as illustrated in Fig. 5, which in turn, could prove to be favorable in terms of neuropsychological performance. We did not detect associations between substance use and neurochemical changes at autopsy using a self report survey, probably because a postmortem survey is affected by multiple confounding factors during a human lifetime. Drugs are often abused intermittently, using complex combinations of substances, for varying durations. Acute intoxication, binging, fatal overdoses and undocumented abstinence periods all can influence synaptic tone, yet cannot be controlled for generally in an autopsy survey. Another potentially important influence to consider is nicotine dependence, which can stimulate dopamine release in the striatal reward pathway and produce loss of radiotracer ligand binding to $D R D 2$. Nicotine use modified the strength of the association between HIV infection and striatal DAT binding availability in the study by Chang et al. (2008). Smoking histories were not available in the autopsy survey, so the lower DRD2L expression with HIV/ AIDS might have been influenced by nicotine use. The great complexity introduced by multiple historical variables suggests that the influence of substance abuse needs to be unraveled using corollary experimental paradigms of HIV infection.

In addition to acquired factors that occur intermittently before death, innate factors such as host genetic polymorphism might be important. The host genome could produce enduring effects on synaptic mRNA regulation primarily because it does not fluctuate with time. $D R D 2 L$ gene polymorphism modifies DRD2L mRNA expression and changes the functional output of the DLPFC (Duan et al. 2003; Zhang et al. 2007). As well, enzymatic degradation of synaptic dopamine by catechol-O-methyltransferase (COMT) is influenced by host polymorphism of COMT which in turn, can modify dopaminergic output of the DLPFC (Egan et al. $2001)$. In that scenario a subject would acquire low $D R D 2 L$ or PENK expression (and potential synaptic accommodation) prior to acquiring HIV/AIDS. If host genes can indeed drive $D R D 2 L$ expression, vulnerable subjects with inherently less favorable genes, and weaker synaptic accommodation, could be identified a priori and treated aggressively with measures to stimulate accommodation and promote more favorable neuropsychological outcomes. Similarly, less vulnerable subjects might be identified clinically. Neuropharmacological manipulation of opioidergic and dopaminergic tone represents a logical way to mimic naturally occurring synaptic accommodation to improve neurocognitive function (Hille et al. 2001; Cohen and Servan-Schreiber 1992). The suggested approach acts downstream from brain neuroimmune activation, and is an attractive site of action because neural immunity must be preserved in order to control brain HIV-1 replication, suppress viral latency or participate in therapeutic virus eradication paradigms.

Summary Neurochemical measurements in 512 autopsy brain specimens lend strong credence to the hypothesis that synaptic modulation occurs often in the DLPFC of subjects with HIV/ AIDS. Dopaminergic and opioidergic neurotransmitter systems were regulated transcriptionally and exhibited various linkages to brain neuroimmunity, brain pathology and brain function. The most important association that was established is that decreased expression of $D R D 2 L$ in frontal neocortex was linked to a more favorable neuropsychological outcome. Coordinated neuropharmacological manipulation of such neurotransmitter imbalances could modulate the brain circuits that drive neurocognitive impairment or provide synaptic accommodation in HIV/AIDS. Protecting circuit level function pharmacodynamically is a therapeutic approach that preserves host neural immunity and is potentially complementary to HAART.

Acknowledgements We thank Steve Schuenke for preparing graphic art including the drawing in Fig. 5. The work was supported by R01MH79886 and U01-MH083507 from the National Institutes of Health. Specimens were provided by the National NeuroAIDS Tissue Consortium which obtained support from U01-MH83506, U01-MH083545, U01-MH083501, U01-MH83500.

Conflict of Interest The authors declare that they have no competing interests or conflicts of interest.

Open Access This article is distributed under the terms of the Creative Commons Attribution License which permits any use, distribution, and reproduction in any medium, provided the original author(s) and the source are credited.

\section{References}

Achim CL, Wang R, Miners DK, Wiley CA (1994) Brain viral burden in HIV infection. J Neuropathol Exp Neurol 53(3):284-294 
Albensi BC, Mattson MP (2000) Evidence for the involvement of TNF and NF-KB in hippocampal synaptic plasticity. Synapse 35 (2): $151-159$

Angulo JA, Coirini H, Ledoux M, Schumacher M (1991) Regulation by dopaminergic neurotransmission of dopamine D2 mRNA and receptor levels in the striatum and nucleus accumbens of the rat. Brain Res Mol Brain Res 11(2):161-166

Antinori A, Arendt G, Becker JT et al (2007) Updated research nosology for HIV-associated neurocognitive disorders. Neurology 69 (18):1789-1799

Antonini A, Leenders KL, Reist H, Thomann R, Beer HF, Locher J (1993) Effect of age on D2 dopamine receptors in normal human brain measured by positron emission tomography and $11 \mathrm{C}$ raclopride. Arch Neurol 50(5):474-80

Baddeley A (2003) Working memory: looking back and looking forward. Nat Rev Neurosci 4(10):829-839

Benjamini Y, Yekutieli D (2001) The control of the false discovery rate in multiple testing under dependency. Ann Stat 29(4):1165-1188

Berger JR, Arendt G (2000) HIV dementia: the role of the basal ganglia and dopaminergic systems. J Psychopharmacol 14(3):214-221

Berger-Greenstein JA, Cuevas CA, Brady SM, Trezza G, Richardson MA, Keane TM (2007) Major depression in patients with HIV/ AIDS and substance abuse. AIDS Patient Care STDS 21 (12):942-955

Boehm U, Klamp T, Groot M, Howard JC (1997) Cellular responses to interferon-gamma. Ann Rev Immunol 15:749-795

Boulanger LM (2004) MHC class I in activity-dependent structural and functional plasticity. Neuron Glia Biol 1(3):283-289

Boulanger LM (2009) Immune proteins in brain development and synaptic plasticity. Neuron 64(1):93-109

Boulanger LM, Huh GS, Shatz CJ (2001) Neuronal plasticity and cellular immunity: shared molecular mechanisms. Curr Opin Neurobiol 11(5):568-578

Brask J, Kristensson K, Hill RH (2004) Exposure to interferon- $\gamma$ during synaptogenesis increases inhibitory activity after a latent period in cultured rat hippocampal neurons. Eur J Neurosci 19(12):3193-3201

Budka H, Wiley CA, Kleihues P et al (1991) HIV-associated disease of the nervous system: Review of nomenclature and proposal for neuropathology-based terminology. Brain Pathol 1(3):143-152

Chang L, Wang GJ, Volkow ND, Ernst T, Telang F, Logan J, Fowler JS (2008) Decreased brain dopamine transporters are related to cognitive deficits in HIV patients with or without cocaine abuse. Neuroimage 42:869-878

Citri A, Malenka RC (2008) Synaptic plasticity: multiple forms, functions, and mechanisms. Neuropsychopharmacology 33(1):18-41

Clifford DB, Evans SR, Yang Y et al (2005) The neuropsychological and neurological impact of hepatitis $\mathrm{C}$ virus co-infection in HIVinfected subjects. AIDS 19(Suppl 3):S64-S71

Cohen JD, Servan-Schreiber D (1992) Context, cortex, and dopamine: a connectionist approach to behavior and biology in schizophrenia. Psychol Rev Jan 99(1):45-77

Cohen JD, Braver TS, Brown JW (2002) Computational perspectives on dopamine function in prefrontal cortex. Curr Opin Neurobiol 12(2):223-229

Cools R, D'Esposito M (2011) Inverted-U-shaped dopamine actions on human working memory and cognitive control. Biol Psychiatry 69(12):113-125

Cunningham AJ, Murray CA, O’Neill LA et al (1996) Interleukin-1 $\beta$ (IL-1 $\beta$ ) and tumour necrosis factor (TNF) inhibit long-term potentiation in the rat dentate gyrus in vitro. Neurosci Lett 203 (1):17-20

D’Arcangelo G, Grassi F, Ragozzino D, Santoni A, Tancredi V, Eusebi F (1991) Interferon inhibits synaptic potentiation in rat hippocampus. Brain Res 564(2):245-248

Da Cunha A, Rausch DM, Eiden LE (1995) An early increase in somatostatin mRNA expression in the frontal cortex of rhesus monkeys infected with simian immunodeficiency virus. Proc Natl Acad Sci USA 92(5):1371-1375

Dafny N (1998) Is interferon-alpha a neuromodulator? Brain Res Brain Res Rev 26(1):1-15

Dafny N, Yang PB (2005) Interferon and the central nervous system. Eur J Pharmacol 523:1-15

Dafny N, Prieto-Gomez B, Dong WQ, Reyes-Vazquez C (1996) Interferon modulates neuronal activity recorded from the hypothalamus, thalamus, hippocampus, amygdala and the somatosensory cortex. Brain Res 734(1-2):269-274

De Vries TJ, Shippenberg TS (2002) Neural systems underlying opiate addiction. J Neurosci 22(9):3321-3325

Delhaye S, Paul S, Gjon B, Minet M, Weber F, Staeheli P, Michiels T (2006) Neurons produce type I interferon during viral encephalitis. Proc Natl Acad Sci USA 103(20):7835-7840

Di Filippo M, Sarchielli P, Picconi B, Calabresi P (2008) Neuroinflammation and synaptic plasticity: theoretical basis for a novel, immune-centered, therapeutic approach to neurological disorders. Trends Pharmacol Sci 29(8):402-412

Dickson DW, Crystal HA, Mattiace LA, Masur DM, Blau AD, Davies P, Yen SH, Aronson MK (1992) Identification of normal and pathological aging in prospectively studied nondemented elderly humans. Neurobiol Aging 13:179-189

Duan J, Wainwright MS, Comeron JM, Saitou N, Sanders AR, Gelernter J, Gejman PV (2003) Synonymous mutations in the human dopamine receptor D2 (DRD2) affect mRNA stability and synthesis of the receptor. Hum Mol Genet 12(3):205-216

Efron B (1979) Bootstrap methods: Another look at the jackknife. Ann Stat 7(1):1-26

Egan MF, Goldberg TE, Kolachana BS et al (2001) Effect of COMT Val108/158 Met genotype on frontal lobe function and risk for schizophrenia. Proc Natl Acad Sci USA 98 (12):6917-6922

Elgersma Y, Silva AJ (1999) Molecular mechanisms of synaptic plasticity and memory. Curr Opin Neurobiol 9(2):209-213

El-Ghundi M, O'Dowd BF, George SR (2007) Insights into the role of dopamine receptor systems in learning and memory. Rev Neurosci 18(1):37-66

Ernst T, Chang L, Jovicich J, Ames N, Arnold S (2002) Abnormal brain activation on functional MRI in cognitively asymptomatic HIV patients. Neurology 59(9):1343-1349

Ernst T, Jiang CS, Nakama H, Buchthal S, Chang L (2010) Lower brain glutamate is associated with cognitive deficits in HIV patients: A new mechanism for HIV-associated neurocognitive disorder. J Magn Reson Imaging 32(5):1045-1053

Everall I, Vaida F, Khanlou N, Lazzaretto D, Achim C, Letendre S et al (2009) Cliniconeuropathologic correlates of human immunodeficiency virus in the era of antiretroviral therapy. J Neurovirol 15(56):360-370

Ferrarese C, Aliprandi A, Tremolizzo L et al (2001) Increased glutamate in CSF and plasma of patients with HIV dementia. Neurology 57(4):671-675

Floresco SB, Magyar O (2006) Mesocortical dopamine modulation of executive functions: beyond working memory. Psychopharmacology (Berl) 188(4):567-585

Garthwaite J, Boulton CL (1995) Nitric oxide signaling in the central nervous system. Annu Rev Physiol 57:683-706

Gaskill PJ, Calderon TM, Luers AJ, Eugenin EA, Javitch JA, Berman JW (2009) Human immunodeficiency virus (HIV) infection of human macrophages is increased by dopamine: a bridge between HIV-associated neurologic disorders and drug abuse. Am J Pathol 175(3):1148-1159

Gelbard HA, Dewhurst S, Maggirwar SB, Kiebala M, Polesskaya O, Gendelman HE (2010) Rebuilding synaptic architecture in HIV-1 associated neurocognitive disease: A therapeutic strategy based on modulation of mixed lineage kinase. Neurotherapeutics 7(4):392-398 
Gelman BB (2007) The Neuropathology of HIV. Chapter 18 in Handbook of Clinical Neurology, volume 84 (3d series), Portegies $P$, Berger JR, (eds), HIV/AIDS and the Nervous System. Elsevier B. V., pp 291-307

Gelman BB, Nguyen TP (2010) Synaptic proteins linked to HIV-1 infection and immunoproteasome induction: proteomic analysis of human synaptosomes. J Neuroimmune Pharmacol 5(1):92-102

Gelman BB, Dholakia S, Casper K, Kent TA, Cloyd MW, Freeman D $\operatorname{Jr}$ (1996) Expansion of the cerebral ventricles and correlation with AIDS neuropathology in 232 patients. Arch Pathol Lab Med 120 (9):866-871

Gelman BB, Soukup VM, Schuenke KW et al (2004) Acquired neuronal channelopathies in HIV-associated dementia. J Neuroimmunol 157(1-2):111-119

Gelman BB, Spencer JA, Holzer CE 3rd, Soukup VM (2006) Abnormal striatal dopaminergic synapses in National NeuroAIDS Tissue Consortium subjects with HIV encephalitis. J Neuroimmune Pharmacol 1:410-420

Gerfen CR, Engber TM, Mahan LC et al (1990) D1 and D2 dopamine receptor-regulated gene expression of striatonigral and striatopallidal neurons. Science 250(4986):1429-1432

Gerfen CR, McGinty JF, Young WS 3rd (1991) Dopamine differentially regulates dynorphin, Substance P, and enkephalin expression in striatal neurons: in situ hybridization histochemical analysis. J Neurosci 11(4):1016-1031

Glass JD, Fedor H, Wesselingh SL, McArthur JC (1995) Immunocytochemical quantitation of human immunodeficiency virus in the brain: Correlations with dementia. Ann Neurol 38(5):755-762

Gobin SJ, van Zutphen M, Woltman AM, van den Elsen PJ (1999) Transactivation of classical and nonclassical HLA class I genes through the IFN-stimulated response element. J Immunol 163(3):1428-1434

Goddard CA, Butts DA, Shatz CJ (2007) Regulation of CNS synapses by neuronal MHC class I. Proc Natl Acad Sci USA 104(16):6628-6633

Goldman-Rakic PS (1996) Regional and cellular fractionation of working memory. Proc Natl Acad Sci USA 93(24):13473-13480

Goldman-Rakic PS (1998) The cortical dopamine system: role in memory and cognition. Adv Pharmacol 42:707-711

Goldstein RZ, Volkow ND (2002) Drug addiction and its underlying neurobiological basis: neuroimaging evidence for the involvement of the frontal cortex. Am J Psychiatry 159(10):1642-1652

Gulledge AT, Jaffe DB (1998) Dopamine decreases the excitability of layer $\mathrm{V}$ pyramidal cells in the rat prefrontal cortex. J Neurosci 18 (21):9139-9151

Hadjilambreva G, Mix E, Rolfs A, Müller J, Strauss U (2005) Neuromodulation by a cytokine: Interferon- $\beta$ differentially augments neocortical neuronal activity and excitability. J Neurophysiol 93 (2):843-852

Heaton RK, Clifford DB, Franklin DR Jr, Woods SP, Ake C et al (2010) HIV-associated neurocognitive disorders persist in the era of potent antiretroviral therapy. Neurology 75(23):2087-2096

Hille CJ, Fox SH, Maneuf YP, Crossman AR, Brotchi JM (2001) Antiparkinsonian action of a delta opioid agonist in rodent and primate models of Parkinson's disease. Exp Neurol 172(1):189-198

Ho WZ, Douglas SD (2004) Substance P and neurokinin-1 receptor modulation of HIV. J Neuroimmunol 157(1):48-55

Hobart M, Ramassar V, Goes N, Urmson J, Halloran PF (1997) IFN regulatory factor- 1 plays a central role in the regulation of the expression of class I and II MHC genes in vivo. J Immunol 158 (9):4260-4269

Hriso E, Kuhn T, Masdeu JC, Grundman M (1991) Extrapyramidal symptoms due to dopamine-blocking agents in patients with AIDS encephalopathy. Am J Psychiatry 148(11):1558-1561

Ito H, Kodaka F, Takahashi $\mathrm{H}$ et al (2011) Relation between presynaptic and postsynaptic dopaminergic functions measured by positron emission tomography: Implication of dopaminergic tone. J Neurosci 31(21):7886-7890
Jakubs K, Bonde S, Losif RE et al (2008) Inflammation regulates functional integration of neurons born in adult brain. J Neurosci 28(47):12477-12488

Jankowsky JL, Patterson PH (1999) Cytokine and growth factor involvement in long-term potentiation. Mol Cell Neurosci 14 (6):273-286

Kaul M, Lipton SA (2006) Mechanisms of neuroimmunity and neurodegeneration associated with HIV-1 infection and AIDS. J Neuroimmune Pharmacol 1(2):138-151

Kawasaki Y, Zhang L, Cheng JK, Ji RR (2008) Cytokine mechanisms of central sensitization: Distinct and overlapping role of interleukin-1 $\beta$ interleukin- 6 , and tumor necrosis factor- $\alpha$ in regulating synaptic and neuronal activity in the superficial spinal cord. J Neurosci 28 (20):5189-5194

Kellendonk C, Simpson EH, Polan HJ et al (2006) Transient and selective overexpression of dopamine $\mathrm{D} 2$ receptors in the striatum causes persistent abnormalities in prefrontal cortex functioning. Neuron 49(4):603-615

Kennedy SE, Koeppe RA, Young EA, Zubieta JK (2006) Dysregulation of endogenous opioid emotion regulation circuitry in major depression in women. Arch Gen Psychiatry 63(11):1199-1208

Khairova RA, Machado-Vieiraa R, Du J, Manjia HK (2009) A potential role for pro-inflammatory cytokines in regulating synaptic plasticity in major depressive disorder. Int J Neuropsychopharmacol 12(4):561-578

Kim IJ, Beck HN, Lein PJ, Higgins D (2002) Interferon gamma induces retrograde dendritic retraction and inhibits synapse formation. J Neurosci 22(11):4530-4539

Koutsilieri E, Czub S, Scheller C, Sopper S, Tatschner T, Stahl-Hennig C, ter Meulen V, Riederer P (2000) Brain choline acetyltransferase reduction in SIV infection. An index of early dementia? Neuroreport 11(11):2391-2393

Koutsilieri E, Scheller C, Sopper S, Gotz ME, Gerlach M, Meulen V, Riederer P (2001a) Selegiline completely restores choline acetyltransferase activity deficits in simian immunodeficiency infection. Eur J Pharmacol 411(1-2):R1-R2

Koutsilieri E, ter Meulen V, Riederer P (2001b) Neurotransmission in HIV associated dementia: a short review. J Neural Transm 108 (6):767-775

Kovács GL, De Wied DD (1994) Peptidergic modulation of learning and memory processes. Pharmacol Rev 46(3):269-291

Kroener S, Chandler LJ, Phillips PE, Seamans JK (2009) Dopamine modulates persistent synaptic activity and enhances the signal-to-noise ratio in the prefrontal cortex. PLoS One 4(8): e 6507

Lidow MS, Wang F, Cao Y, Goldman-Rakic PS (1998) Layer V neurons bear the majority of mRNAs encoding the five distinct dopamine receptor subtypes in the primate prefrontal cortex. Synapse 28(1):10-20

Low KG, Allen RG, Melner MH (1992) Differential regulation of proenkephalin expression in astrocytes by cytokines. Endocrinology 131(4):1908-1914

Maher FO, Clarke RM, Kelly A, Nally RE, Lynch MA (2006) Interaction between interferon gamma and insulin-like growth factor-1 in hippocampus impacts on the ability of rats to sustain long-term potentiation. J Neurochem 96(6):1560-1571

Malenka RC, Nicoll RA (1993) NMDA-receptor-dependent synaptic plasticity: multiple forms and mechanisms. Trends Neurosci 16 (12):521-527

Manéglier B, Guillemin GJ, Clayette P et al (2008) Serotonin decreases HIV-1 replication in primary cultures of human macrophages through 5-HT1A receptors. Br J Pharmacol 154(1):174-182

Mansour A, Thompson RC, Akil H, Watson SJ (1993) Delta opioid receptor mRNA distribution in the brain: comparison to delta receptor binding and proenkephalin. J Chem Neuroanat 6 (6):351-362 
Martin E, Nathan C, Xie QW (1994) Role of interferon regulatory factor 1 in induction of nitric oxide synthase. J Exp Med 180 (2):977-984

Masliah E, Heaton RK, Marcotte TD et al (1997) Dendritic injury is a pathological substrate for human immunodeficiency virus-related cognitive disorders. Ann Neurol 42(6):963-972

Masliah E, DeTeresa RM, Mallory ME, Hansen LA (2000) Changes in pathological findings at autopsy in AIDS cases for the last 15 years. AIDS 14(1):69-74

Masliah E, Roberts ES, Langford D et al (2004) Patterns of gene dysregulation in the frontal cortex of patients with HIV encephalitis. J Neuroimmunol 157(1-2):163-175

McArthur JC, Steiner J, Sacktor N, Nath A (2010) Human immunodeficiency virus-associated neurocognitive disorders: mind the gap. Ann Neurol 67(6):699-714

McGinty JF, Van der Kooy D, Bloom FE (1984) The distribution and morphology of opioid peptide immunoreactive neurons in the cerebral cortex of rats. J Neurosci 4(4):1104-1117

Meisner F, Scheller C, Kneitz S, Sopper S, Neuen-Jacob E, Riederer P, ter Meulen V, Koutsilieri E (2008) Memantine upregulates BDNF and prevents dopamine deficits in SIV-infected macaques: a novel pharmacological action of memantine. Neuropsychopharmacology 33(9):2228-2236

Melrose RJ, Tinaz S, Castelo JM, Courtney MG, Stern CE (2008) Compromised fronto-striatal functioning in HIV: An fMRI investigation of semantic event sequencing. Behav Brain Res 188 (2):337-347

Mendoza-Fernández V, Andrew RD, Barajas-López C (2000) Interferon- $\alpha$ inhibits long-term potentiation and unmasks a long-term depression in the rat hippocampus. Brain Res 885 (1):14-24

Meyerhoff DJ, Bloomer C, Cardenas V, Norman D, Weiner MW, Fein G (1999) Elevated subcortical choline metabolites in cognitively and clinically asymptomatic HIV + patients. Neurology 52(5):995-1003

Mizuno T, Zhang G, Takeuchi H et al (2008) Interferon- $\gamma$ directly induces neurotoxicity through a neuron specific, calciumpermeable complex of IFN- $\gamma$ receptor and AMPA GluR1 receptor. FASEB J 22(6): 1797-1806

Monte-Silva K, Kuo MF, Thirugnanasambandam N, Liebetanz D, Paulus W, Nitsche MA (2009) Dose-dependent inverted Ushaped effect of dopamine (D2-like) receptor activation on focal and nonfocal plasticity in humans. J Neurosci 29(19):6124-6131

Morgello S, Gelman BB, Kozlowski P, Vinters H (2001) The national neuroAIDS tissue consortium: a new paradigm in brain banking with an emphasis on infectious disease. Neuropathol Appl Neurobiol 27(4):326-335

Morgello S, Holzer CE 3rd, Ryan E, Young C, Naseer M, Castellon SA, Frol AB, Atkinson JH, Gelman BB, Grant I, Singer EJ (2006) Inter-rater reliability of the psychiatric research interview for substance and mental disorders in an HIV-infected cohort: Experience of the national neuroAIDS tissue consortium. Int J Methods Psychiatr Res 15(3):131-138

Morris BJ, Hunt SP (1991) Proenkephalin mRNA levels in rat striatum are increased and decreased, respectively, by selective $D_{2}$ and $D_{1}$ dopamine receptor antagonists. Neurosci Lett 125(2):201-204

Murray MF (2003) Tryptophan depletion and HIV infection: a metabolic link to pathogenesis. Lancet Infect Dis 3:644-652

Nagano-Saito A, Leyton M, Monchi O, Goldberg YK, He Y, Dagher A (2008) Dopamine depletion impairs frontostriatal functional connectivity during a set-shifting task. J Neurosci 28(14):3697-3706

Nath A, Anderson C, Jones M et al (2000) Neurotoxicity and dysfunction of dopaminergic systems associated with AIDS dementia. J Psychopharmacol 14(3):222-227
Nath A, Hauser KF, Wojna V et al (2002) Molecular basis for interactions of HIV and drugs of abuse. J Acquir Immune Defic Syndr 31(2):S62-S69

Negro A, Tavella A, Facci L, Callegaro L, Skaper SD (1992) Interleukin-1 beta regulates proenkephalin gene expression in astrocytes cultured from rat cortex. Glia 6(3):206-212

Neumann H, Schmidt H, Cavalié A, Jenne D, Wekerle H (1997) Major histocompatibility complex (MHC) class I gene expression in single neurons of the central nervous system: differential regulation by interferon (IFN)- $\gamma$ and tumor necrosis factor (TNF)- $\alpha$. J Exp Med 185(2):305-316

Nguyen TN, Soukup VM, Gelman BB (2010) Persistent hijacking of brain proteasomes in HIV-associated dementia. Am J Pathol 176 (2):893-902

O'Connor JJ, Coogan AN (1999) Actions of the pro-inflammatory cytokine IL-1 beta on central synaptic transmission. Exp Physiol 84(4):601-614

Otani S, Daniel H, Roisin MP, Crepel F (2003) Dopaminergic modulation of long-term synaptic plasticity in rat prefrontal neurons. Cerebr Cortex 13(11):1251-1256

Ottowitz WE, Dougherty DD, Savage CR (2002) The neural network basis for abnormalities of attention and executive function in major depressive disorder: Implications for application of the medical disease model to psychiatric disorders. Harvard Rev Psychiatry 10(2):86-99

Ovadia H, Magenheim Y, Behar O, Rosen H (1996) Molecular characterization of immune derived proenkephalin mRNA and the involvement of the adrenergic system in its expression in rat lymphoid cells. J Neuroimmunol 68(1-2):77-83

Palmer S, Wiegand AP, Maldarelli F et al (2003) New real-time reverse transcriptase-initiated PCR assay with single-copy sensitivity for human immunodeficiency virus type 1 RNA in plasma. J Clin Microbiol 41(10):4531-4536

Parks RW, Loewenstein DA, Dodrill KL et al (1988) Cerebral metabolic effects of a verbal fluency test: a PET scan study. J Clin Exp Neuropsychol 10(5):565-575

Peckys D, Hurd YL (2001) Prodynorphin and k opioid receptor mRNA expression in the cingulate and prefrontal cortices of subjects diagnosed with schizophrenia or affective disorders. Brain Research Bull 55(5):619-624

Przewłocka B, Lasoń W (1995) Adaptive changes in the proenkephalin and D2 dopamine receptor mRNA expression after chronic cocaine in the nucleus accumbens and striatum of the rat. Eur Neuropsychopharmacol 5(4):465-469

Ross FM, Allan SM, Rothwell NJ, Verkhratsky A (2003) A dual role for interleukin-1 in LTP in mouse hippocampal slices. J Neuroimmunology 144(1-2):61-67

Sarter M, Podell M (2000) Preclinical psychopharmacology of AIDSassociated dementia: lessons to be learned from the cognitive psychopharmacology of other dementias. J Psychopharmacol 14 (3):197-204

Sas AR, Bimonte-Nelson H, Smothers CT, Woodward J, Tyor WR (2009) Interferon- $\alpha$ causes neuronal dysfunction in encephalitis. J Neurosci 29(12):3948-3955

Sawaguchi T, Matsumura M, Kubota K (1990) Effects of dopamine antagonists on neuronal activity related to a delayed response task in monkey prefrontal cortex. J Neurophysiol 63(6):1401-1412

Schlosser R, Hutchinson M, Joseffer S et al (1998) Functional magnetic resonance imaging of human brain activity in a verbal fluency task. J Neurol Neurosurg Psychiatry 64(4):492-498

Schroecksnadel K, Zangerle R, Bellmann-Weiler R et al (2007) Indoleamine-2, 3-dioxygenase and other interferon-gammamediated pathways in patients with human immunodeficiency virus infection. Curr Drug Metab 8(3):225-236 
Seamans JK, Yang CR (2004) The principal features and mechanisms of dopamine modulation in the prefrontal cortex. Prog Neurobiol 74(1): $1-58$

Sesack SR, Carr DB (2002) Selective prefrontal cortex inputs to dopamine cells: implications for schizophrenia. Physiol Behav 77(4-5):513-517

Squire LR, Zola-Morgan S (1991) The medial temporal lobe memory system. Science 253(5026):1380-1386

Steiner H, Gerfen CR (1999) Enkephalin regulates acute D2 dopamine receptor antagonist-induced immediate-early gene expression in striatal neurons. Neuroscience 88(3):795-810

Steinmetz CC, Turrigian GG (2010) Tumor necrosis factor- $\alpha$ signaling maintains the ability of cortical synapses to express synaptic scaling. J Neurosci 30(44):14685-14690

Stellwagen D, Malenka RC (2006) Synaptic scaling mediated by glial TNF- $\alpha$. Nature 440(7087):1054-1059

Tancredi V, D’Arcangelo G, Grassi F, Tarronic P, Palmieri G, Santoni A, Eusebi F (1992) Tumor necrosis factor alters synaptic transmission in rat hippocampal slices. Neurosci Lett 146(2):176-178

Theofilopoulos AN, Baccala R, Beutler B, Kono DH (2005) Type I interferons $(\alpha / \beta)$ in immunity and autoimmunity. Annu Rev Immunol 23:307-336

Tierney PL, Thierry AM, Glowinski J, Deniau JM, Gioanni Y (2008) Dopamine modulates temporal dynamics of feedforward inhibition in rat prefrontal cortex in vivo. Cereb Cortex 18(10):2251-2262

Trantham-Davidson H, Neely LC, Lavin A, Seamans JK (2004) Mechanisms underlying differential D1 versus D2 dopamine receptor regulation of inhibition in prefrontal cortex. J Neurosci 24(47):10652-10659

Tremblay LK, Naranjo CA, Graham SJ et al (2005) Functional neuroanatomical substrates of altered reward processing in major depressive disorder revealed by a dopaminergic probe. Arch Gen Psychiatry 62(11):1228-1236

van der Werf-Eldering MJ, Burger H, Holthausen EAE, Aleman A, Nolen WA (2010) Cognitive functioning in patients with bipolar disorder: association with depressive symptoms and alcohol use. PLoS ONE 5(9):e13032. doi:10.1371/journal.pone.0013032

Verdejo A, Toribiob I, Orozcoa C, Puentec KL, Pérez-Garcíaa M (2005) Neuropsychological functioning in methadone maintenance patients versus abstinent heroin abusers. Drug Alcohol Depend 78 (3):283-288

Victório SC, Havton LA, Oliveira AL (2010) Absence of IFN $\gamma$ expression induces neuronal degeneration in the spinal cord of adult mice. J Neuroinflammation 7:77. doi:10.1186/1742-2094-7-77

Vikman KS, Owe-Larsson B, Brask J et al (2001) Interferon-gammainduced changes in synaptic activity and AMPA receptor clustering in hippocampal cultures. Brain Res 896(1-2):18-29
Volkow NC, Fowler JS, Wang GJ (1999) Imaging studies on the role of dopamine in cocaine reinforcement with addiction in humans. J Psychopharmacology 13:337-345

Volkow N, Logan J, Fowler J, Wang G, Gur R, Wong C, Felder C, Gatley S, Ding Y, Hitzmann R, Pappas N (2000) Association between age-related decline in brain dopamine activity and impairment in frontal and cingulate metabolism. Am J Psychiatry 157:75-80

Wang GJ, Chang L, Volkow ND et al (2004a) Decreased brain dopaminergic transporters in HIV-associated dementia patients. Brain 127(11):2452-2458

Wang M, Vijayraghavan S, Goldman-Rakic PS (2004b) Selective D2 receptor actions on the functional circuitry of working memory. Science 303(5659):853-856

Wetzel MA, Steele AD, Eisenstein TK et al (2000) $\mu$-opioid induction of monocyte chemoattractant protein-1, RANTES, and IFN- $\gamma$ inducible protein-10 expression in human peripheral blood mononuclear cells. J Immunol 165(11):6519-6524

Wiley CA, Achim CL (1994) Human immunodeficiency virus encephalitis is the pathological correlate of dementia in acquired immunodeficiency syndrome. Ann Neurol 36(4):673-676

Wilkinson LS (1997) The nature of interactions involving prefrontal and striatal dopamine systems. J Psychopharmacol $11: 143-150$

Wolf ME (2002) Addiction: making the connection between behavioral changes and neuronal plasticity in specific pathways. Mol Interv 2 (3):146-157

Woods SP, Conover E, Rippeth JD et al (2004) Qualitative aspects of verbal fluency in HIV-associated dementia: a deficit in ruleguided lexical-semantic search processes? Neuropsychologia 42 (6):801-809

Woods SP, Moore DJ, Weber E, Grant I (2009) Cognitive neuropsychology of HIV-associated neurocognitive disorders. Neuropsychol Rev 19(2):152-168

Xie CW, Lewis DV (1995) Endogenous opioids regulate long-term potentiation of synaptic inhibition in the dentate gyrus of rat hippocampus. J Neurosci 15(5pt2):3788-3795

Yirmiya R, Goshen I (2011) Immune modulation of learning, memory, neural plasticity and neurogenesis. Brain Behav Immun 25 (2):181-213

Zhang Y, Bertolino A, Fazio L et al (2007) Polymorphisms in human dopamine D2 receptor gene affect gene expression, splicing, and neuronal activity during working memory. Proc Natl Acad Sci USA 104(51):20552-20557

Zhu J, Ananthan S, Mactutus CF, Booze R (2011) Recombinant human immunodeficiency virus-1 transactivator of transcription ${ }^{1-86}$ allosterically modulates dopamine. Synapse 65:1251-1254 